\title{
Silica-supported policresulen as a solid acid catalyst for organic reactions
}

\author{
Kexing Zeng a,t, Zhipeng Huang a, ${ }^{\mathrm{t}}$, Jie Yang a , Yanlong Gu a,b,* \\ a Key Laboratory for Large-Format Battery, Materials and System, Ministry of Education, School of Chemistry and Chemical Engineering, Huazhong Uni- \\ versity of Science and Technology, Wuhan 430074, Hubei, China \\ b State Key Laboratory for Oxo Synthesis and Selective Oxidation, Lanzhou Institute of Chemical Physics, Chinese Academy of Science, Lanzhou 730000, \\ Gansu, China
}

\section{A R T I C L E I N F O}

\section{Article history:}

Received 25 April 2015

Accepted 22 May 2015

Published 20 September 2015

\section{Keywords:}

Acid catalysis

Solid acid

Policresulen

Covalent bond-free immobilization

oxa-Pictet-Spengler reaction

\begin{abstract}
A B S T R A C T
A new type of solid catalyst was prepared by coating a thin layer of policresulen, an inexpensive polymer prepared via condensation of 2-hydroxy-4-methylbenzenesulfonic acid and formaldehyde that has been used as commercially available drug, onto the surface of silica. The policresulen component is insoluble in many organic solvents and can be adsorbed on silica with the aid of hydrogen bonding. The obtained silica/policresulen composite showed remarkable catalytic activity for various organic reactions. In model reactions, the catalyst can be recycled several times without significant loss of activity. The salient features of using this acid catalyst in organic reactions include cost-effectiveness, simple and time-efficient preparation, and the convenience of controlling the acid loading on the solid.
\end{abstract}

(C) 2015, Dalian Institute of Chemical Physics, Chinese Academy of Sciences. Published by Elsevier B.V. All rights reserved.

\section{Introduction}

Acid catalysts have been widely used in both academia and industry, and can be categorized into two major types: homogeneous liquid acids and heterogeneous solid acids [1-3]. Although homogeneous mineral acids, such as $\mathrm{H}_{2} \mathrm{SO}_{4}$ and $\mathrm{HF}$, which are corrosive and toxic, have been widely adopted by chemical industry, with increasing pressure coming from environmental protection there is a need to develop green synthetic systems based on environmentally benign acid catalysts [4-8] The use of heterogeneous solid acid catalysts has the general advantages of easier operation, milder conditions, reduced equipment corrosion, and minimized contamination of the waste streams as well as reusability of the catalyst [9-11]. For this reason, heterogeneous solid acids have been extensively investigated [12-15], and in some chemical processes, their use has already contributed to significant improvement of both the synthetic efficiency and the greenness of the system [16-23]. Despite promising and sometime spectacular results, the practical application of solid acids in industrial processes is still hindered by many factors. Among all the methods used to prepare solid acids, the binding of catalysts to organic polymers or inorganic solids is widely used to produce a stable covalent bond between the acid center and the solid support, and is preferable to reduce the chance of leaching [24-26]. The synthesis of some solid acids with this method, however, involves

\footnotetext{
* Corresponding author. Tel: +86-027-87543032; Fax: +86-027-87544532; E-mail: klgyl@hust.edu.cn

+ These authors contributed equally to this work

This work was supported by the National Natural Science Foundation of China $(21173089,21373093)$, the Fundamental Research Funds for the Central Universities of China (2014ZZGH019), and the Cooperative Innovation Center of Hubei Province.

DOI: 10.1016/S1872-2067(15)60910-X | http://www.sciencedirect.com/science/journal/18722067 | Chin. J. Catal., Vol. 36, No. 9, September 2015
} 
several steps which are rather time-consuming. Furthermore, functionalization of a solid support using covalent bonds often requires harsh reaction conditions and as a consequence, calls for both a support and an acid precursor with sufficient chemical and thermal stability [27]. In many cases, a sophisticated operational procedure is also needed [28]. Therefore, some current solid acid catalysts are rather expensive and are therefore not widely used in synthesis. There thus exists a need to develop new, innovative approaches toward the design of recoverable and reusable solid acid catalysts.

Recently, the concept of solid-supported liquid phase catalysis has experienced a rekindled interest in the catalytic and synthetic community for the preparation of efficient heterogeneous catalytic materials [29-34]. With the aid of a thin layer of less volatile fluid coated onto the surface of solid support, some homogeneous catalysts have been easily immobilized without employing sophisticated operational procedures. In a selected reaction, solid form of the catalyst enables an easy recycling, but the reaction proceeded in microcosmically homogeneous conditions $[35,36]$. Inspired by this elegant strategy, we envision that it may be possible to transfer this concept to the development of a solid acid catalyst. To realize this idea, an acidic species that is amenable to the immobilization step and can stay stable on the surface of solid support is needed.

Policresulen is prepared by the condensation of metacresolsulfonic acid and formaldehyde and is commercially available as a clear red-brown solution. It is available at a low price in a number of countries worldwide [37]. Its systematic name is 2-hydroxy-3,5-bis(4-hydroxy-2-methyl-5-sulfobenzyl)4-methylbenzenesulfonic acid. Policresulen is a topical hemostatic and antisepticwidely used as medicine for treating common anal disorders, such as hemorrhoids, and for gynecological infections [38]. Because the backbone of this reagent contains many hydroxyl and sulfonic acid groups, it is barely soluble in many organic solvents, such as toluene, ethyl acetate, and dichloroethane. The thermal stability and chemical stability of policresulen are quite good, making the extension of its applications to other fields possible. Considering that policresulen is a strong organic acid, and also taking into account its hydrophilic properties, we propose that it may be possible to con- struct a new heterogeneous acid catalyst using this reagent as a homogeneous counterpart in conjunction with silica as a supporting material. Thus, we herein report a new solid acid composed of silica and policresulen that displays remarkable catalytic activity in many organic reactions. Compared with conventional solid acids, such as silica-supported sulfonic acid catalysts and Amberlyst-15, the materials obtained by our method have several advantages including simple and time-efficient preparation, low cost, and controllable sulfonic acid loading as well as tunable catalytic activity.

\section{Experimental}

\subsection{Preparation of $\mathrm{SiO}_{2} /$ policresulen composite catalysts 1a-1d}

In a typical procedure used to prepare silica/policresulen composite catalyst $\mathbf{1 b}$, silica gel (10 g) was added to a $250-\mathrm{mL}$ round-bottomed flask containing a mixture of aqueous policresulen solution (52 wt\%, $2.09 \mathrm{~g}$ ) and ethanol (150 mL). The suspension was stirred at room temperature for $30 \mathrm{~min}$ prior to the removal of the ethanol and water under reduced pressure, affording free-flowing solid $\mathbf{1 b}$. Catalysts with different amounts of loaded policresulen $(\mathbf{1 a}, \mathbf{1 c}, \mathbf{1 d})$ were prepared in an analogous way.

\subsection{Preparation of $\mathrm{TiO}_{2}$-supported benzenesulfonic acid catalyst $\mathbf{1 f}$}

Titanium oxide $(5 \mathrm{~g})$ and toluene $(100 \mathrm{~mL})$ were added to a 250-mL round-bottomed flask equipped with magnetic stirring and a Dean-Stark apparatus. After $10 \mathrm{~h}$ of reflux, 4-hydroxybenzenesulfonic acid (3.87 g) dissolved in acetonitrile $(7 \mathrm{~mL})$ was added to the system and refluxed for another $16 \mathrm{~h}$. At the end of the reaction, the solid was filtered, washed with ethanol $(50 \mathrm{~mL} \times 5)$ and dried under vacuum conditions, yielding catalyst 1f. The ion exchange capacity of this catalyst was measured by titration. The obtained result was in good agreement with elemental analysis of the sulfur and carbon content.

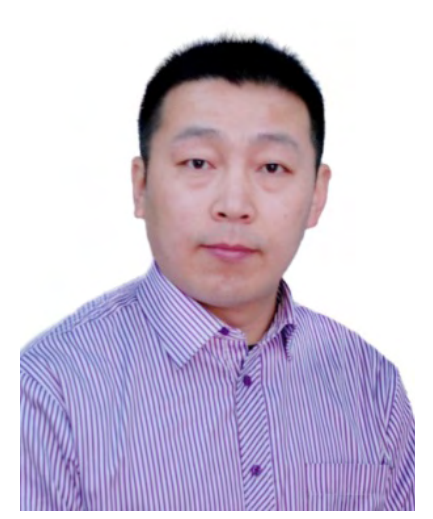

Yanlong Gu (Huazhong University of Science and Technology) received the Catalysis Rising Star Award in 2012, which was presented by The Catalysis Society of China. Professor Yanlong Gu received his Ph.D. degree in Physical Chemistry from Lanzhou Institute of Chemical Physics, Chinese Academy of Sciences, in 2005. He then started a journey as post-doc researcher in the group of Prof. Shu Kobayashi, The University of Tokyo, Japan, and the group of Prof. Francois Jerome, The University of Poitiers, France. Since October 2008, Yanlong Gu become a professor in School of Chemistry and Chemical Engineering, Huazhong University of Science and Technology. In 2009, he received an award of New Century Excellent Talents in Chinese Universities. He has a broad interest in homogeneous and heterogeneous catalysis, organic synthesis, biomass valorization and utilization. His research efforts are focusing on (1) catalysis with acids and ionic liquids; (2) green organic reactions for organic synthesis; and (3) eco-efficient processes based on utilization of biomass. He has published more than 80 research papers, 4 reviews in international peer review journals, and contributed two book chapters in the fields. $H$ index of his publications reached 31 in 2015. Currently, he is a board member of Current Organic Chemistry and a committee member of ionic liquid division, Chemical Industry and Engineering Society of China. 


\subsection{Reactions}

$\mathrm{SiO}_{2} /$ policresulen composite catalyzed $\beta$-alkylation of styrene with benzhydrol. All reactions were conducted in a $10-\mathrm{mL}$ V-type vessel equipped with a triangular magnetic stirrer. In a typical reaction, benzhydrol ( $92.1 \mathrm{mg}, 0.5 \mathrm{mmol})$, styrene $(62.4$ $\mathrm{mg}, 0.6 \mathrm{mmol})$, and $\mathbf{1 b}(20 \mathrm{mg}, 2 \mathrm{~mol} \%)$ were mixed in 1,2-dibromoethane $(1.0 \mathrm{~mL})$ and stirred for $5 \mathrm{~h}$ at $80{ }^{\circ} \mathrm{C}$. After the reaction, the mixture was cooled to room temperature and petroleum ether $(3.0 \mathrm{~mL})$ was added prior to centrifugation. The liquid phase was subjected to isolation with PTLC (PE as eluent). The desired product, $\mathbf{4 a}$, was obtained in a yield of $92 \%$. As for the solid phase, after washing with PE $(3.0 \mathrm{~mL} \times 3)$ and drying under vacuum, $\mathbf{1 b}$ was used in the next run with a similar procedure. Tests of the substrate scope were conducted in the same manner.

$\mathrm{SiO}_{2} /$ policresulen composite catalyzed oxa-Pictet-Spengler reaction. All reactions were conducted in a 10-mL V-type vessel equipped with a triangular magnetic stirrer. In a typical reaction, 2-(3,4-dimethoxyphenyl)ethanol (91.1 $\mathrm{mg}, 0.5 \mathrm{mmol})$, benzaldehyde ( $64.8 \mathrm{mg}, 0.6 \mathrm{mmol})$, and $1 \mathrm{~b}(10 \mathrm{mg}, 1 \mathrm{~mol} \%)$ were mixed in 1,2-dichloroethane $(1.0 \mathrm{~mL})$ and stirred for $5 \mathrm{~h}$ at $80{ }^{\circ} \mathrm{C}$. After the reaction, the mixture was cooled to room temperature and then centrifuged, and the liquid phase was subjected to isolation with PTLC (eluting solvent: ethyl acetate/petroleum ether $=1 / 8$ ). The desired product, $7 \mathbf{a}$, was obtained in a yield of $96 \%$. Tests of the substrate scope were conducted in the same manner. The recycling of $\mathbf{1 b}$ was realized after doubling the dose. After washing the solid phase with PE $(3.0 \mathrm{~mL} \times 3)$ and drying under vacuum, the recovered $\mathbf{1 b}$ was used in the next run with a similar procedure.

$\mathrm{SiO}_{2} /$ policresulen composite catalyzed C3-alkenylation of 2-methylindoles with methyl acetoacetate. The reaction was conducted in a 10-mL V-type vessel equipped with a triangular magnetic stirrer. In a typical reaction, 2-methylindole (65.6, 0.5 $\mathrm{mmol}$ ), methyl acetoacetate (116.1 $\mathrm{mg}, 1.0 \mathrm{mmol}$ ), and 1c (50 $\mathrm{mg}, 10 \mathrm{~mol} \%)$ were mixed in toluene $(1.0 \mathrm{~mL})$ and stirred for $16 \mathrm{~h}$ at $100{ }^{\circ} \mathrm{C}$. After the reaction, the mixture was cooled to room temperature and then centrifuged, and the liquid phase was subjected to isolation with PTLC. The desired product, 10a, was obtained in a yield of $90 \%$. After washing the solid phase with PE $(3.0 \mathrm{~mL} \times 3)$ and drying under vacuum, the recovered 1c was used in the next run with a similar procedure.

$\mathrm{SiO}_{2} /$ policresulen composite catalyzed C3-alkenylation of 2-methylindole with phenylacetaldehyde. The reaction was conducted in a 10-mL of V-type vessel equipped with triangle magnetic stirring. 2-methylindole (65.6, $0.5 \mathrm{mmol}$ ), phenylacetaldehyde ( $90.1 \mathrm{mg}, 0.75 \mathrm{mmol}$ ), ethanol anhydrous (50.6 $\mathrm{mg}, 1.1 \mathrm{mmol})$ and $\mathbf{1 d}(33.3 \mathrm{mg}, 10 \mathrm{~mol} \%)$ were mixed in dichloromethane $(1.0 \mathrm{~mL})$ and stirred for $11 \mathrm{~h}$ at room temperature. After reaction, petroleum ether $(3.0 \mathrm{ml})$ was added prior to centrifuge, the liquid phase was submitted to isolation with PTLC. The desired product, $\mathbf{1 0 b}$, was obtained in a yield of $94 \%$. After washing the solid phase with PE $(3.0 \mathrm{~mL} \times 3)$ and drying under vacuum, the recovered $1 \mathbf{d}$ was used in the next run with a similar procedure.

\subsection{Spectroscopic data of new compounds}

(E)-1-chloro-4-(1-(4-methoxyphenyl)-3-phenylallyl)benzene (4j). Pale yellow liquid; ${ }^{1} \mathrm{H}$ NMR (400 $\left.\mathrm{MHz}, \mathrm{CDCl}_{3}, 25^{\circ} \mathrm{C}\right): \delta=$ $7.34(\mathrm{~d}, J=7.4 \mathrm{~Hz}, 2 \mathrm{H}), 7.27-7.23(\mathrm{~m}, 3 \mathrm{H}), 7.19(\mathrm{t}, J=2.7 \mathrm{~Hz}$, $2 \mathrm{H}), 7.13(\mathrm{~d}, J=8.5 \mathrm{~Hz}, 2 \mathrm{H}), 7.10(\mathrm{~d}, J=8.6 \mathrm{~Hz}, 2 \mathrm{H}), 6.84(\mathrm{~d}, J=$ $8.6 \mathrm{~Hz}, 2 \mathrm{H}$ ), 6.58 (dd, $\left.J_{\mathrm{a}}=7.3 \mathrm{~Hz}, J_{\mathrm{b}}=15.8,1 \mathrm{H}\right), 6.29$ (d, J = 15.9 $\mathrm{Hz}, 1 \mathrm{H}), 4.79$ (d, $J=7.3 \mathrm{~Hz}, 1 \mathrm{H}), 3.75 \mathrm{ppm}(\mathrm{s}, 3 \mathrm{H}) ;{ }^{13} \mathrm{C}$ NMR $(100$ $\left.\mathrm{MHz}, \mathrm{CDCl}_{3}\right): \delta=158.4,142.4,137.2,135.2,132.4,132.2,131.6$, 130.1, 129.6, 128.7, 127.5, 126.4, 114.1., 55.3, 52.8 ppm; HRMS $m / z$ (ESI) calcd. for $\mathrm{C}_{22} \mathrm{H}_{19} \mathrm{ClNaO}[\mathrm{M}+\mathrm{Na}]^{+}: 357.1022$, found 357.1020 .

(E)-1-fluoro-2-(1-(4-methoxyphenyl)-3-phenylallyl)benzene (4k). Pale yellow liquid; ${ }^{1} \mathrm{H}$ NMR $\left(400 \mathrm{MHz}, \mathrm{CDCl}_{3}, 25^{\circ} \mathrm{C}\right): \delta=$ $7.36(\mathrm{~d}, J=7.4 \mathrm{~Hz}, 2 \mathrm{H}), 7.28(\mathrm{t}, J=7.6 \mathrm{~Hz}, 2 \mathrm{H}), 7.22-7.12(\mathrm{~m}$, 5H), 7.10-7.00 (m, 2H), $6.84(\mathrm{~d}, J=8.7 \mathrm{~Hz}, 2 \mathrm{H}), 6.64\left(\mathrm{dd}, J_{\mathrm{a}}=7.2\right.$ $\left.\mathrm{Hz}, J_{\mathrm{b}}=15.8 \mathrm{~Hz}, 1 \mathrm{H}\right), 6.31(\mathrm{~d}, J=15.8 \mathrm{~Hz}, 1 \mathrm{H}), 5.15(\mathrm{~d}, J=7.1 \mathrm{~Hz}$, 1H), $3.76 \mathrm{ppm}(\mathrm{s}, 3 \mathrm{H}) ;{ }^{13} \mathrm{C} \mathrm{NMR}\left(100 \mathrm{MHz}, \mathrm{CDCl}_{3}\right): \delta=161.9$ $159.4,158.3,137.2,134.4,131.6,131.4,130.9,130.8,130.0$, $129.9,129.5,128.6,128.2,128.1,127.4,126.4,124.2,124.1$, 115.7, 115.5, 113.9, 55.3, 46.2, $46.2 \mathrm{ppm}$; HRMS $\mathrm{m} / z$ (ESI) calcd. for $\mathrm{C}_{22} \mathrm{H}_{19} \mathrm{FNaO}[\mathrm{M}+\mathrm{Na}]^{+}: 341.1318$, found 341.1319.

(E)-1-chloro-2-(1-(4-methoxyphenyl)-3-phenylallyl)benzene (41). Pale yellow liquid; ${ }^{1} \mathrm{H}$ NMR ( $\left.400 \mathrm{MHz}, \mathrm{CDCl}_{3}, 25^{\circ} \mathrm{C}\right): \delta=$ 7.36-7.30 (m, 3H), 7.28-7.22 (m, 3H), 7.19-7.09 (m, 5H), 6.82 (d, $J=8.7 \mathrm{~Hz}, 1 \mathrm{H}), 6.59\left(\mathrm{dd}, J_{\mathrm{a}}=1.2 \mathrm{~Hz}, J_{\mathrm{b}}=15.9 \mathrm{~Hz}, 1 \mathrm{H}\right), 6.24(\mathrm{~d}$, $J=15.8 \mathrm{~Hz}, 1 \mathrm{H}), 5.33(\mathrm{~d}, J=6.6 \mathrm{~Hz}, 1 \mathrm{H}), 3.73 \mathrm{ppm}(\mathrm{s}, 3 \mathrm{H}) ;{ }^{13} \mathrm{C}$ NMR (100 MHz, $\left.\mathrm{CDCl}_{3}\right): \delta=158.4,141.3,137.3,134.3,134.2$, 131.9, 131.8, 130.2, 129.9, 128.7, 128.6, 127.9, 127.5, 127.0, 126.5, 113.9, 55.3, $49.5 \mathrm{ppm}$; HRMS $\mathrm{m} / \mathrm{z}$ (ESI) calcd. for $\mathrm{C}_{22} \mathrm{H}_{19} \mathrm{ClNaO}[\mathrm{M}+\mathrm{Na}]+:$ 357.1022, found 357.1025.

(E)-1-chloro-4-(3-phenyl-1-(p-tolyl)allyl)benzene (4m). Pale yellow liquid; ${ }^{1} \mathrm{H}$ NMR (400 MHz, $\mathrm{CDCl}_{3}, 25^{\circ} \mathrm{C}$ ): $\delta=7.33(\mathrm{~d}, J=$ $7.2 \mathrm{~Hz}, 2 \mathrm{H}), 7.28-7.21(\mathrm{~m}, 4 \mathrm{H}), 7.21-7.16(\mathrm{~m}, 1 \mathrm{H}), 7.15-7.06$ $(\mathrm{m}, 6 \mathrm{H}), 6.59\left(\mathrm{dd}, \mathrm{J}_{\mathrm{a}}=7.4 \mathrm{~Hz}, \mathrm{~J}_{\mathrm{b}}=15.8 \mathrm{~Hz}, 1 \mathrm{H}\right), 6.30(\mathrm{~d}, J=15.8$ $\mathrm{Hz}, 1 \mathrm{H}), 4.79$ (d, $J=7.4 \mathrm{~Hz}, 1 \mathrm{H}), 2.30 \mathrm{ppm}(\mathrm{s}, 3 \mathrm{H}) ;{ }^{13} \mathrm{C}$ NMR $(100$ $\mathrm{MHz}, \mathrm{CDCl}_{3}$ ): $\delta=142.4,140.1,137.2,136.3,132.3,132.3,131.7$, 130.1, 129.4, 128.7, 128.6, 128.6, 127.5, 126.4, 53.3, 21.1 ppm; HRMS $m / z$ (ESI) calcd. for $\mathrm{C}_{22} \mathrm{H}_{19} \mathrm{ClNa}[\mathrm{M}+\mathrm{Na}]^{+}: 341.1073$, found 341.1071 .

6,7-Dimethoxy-1-phenethyl-isochroman (7k). Yellow liquid; ${ }^{1} \mathrm{H} \mathrm{NMR}\left(400 \mathrm{MHz}, \mathrm{CDCl}_{3}, 25^{\circ} \mathrm{C}\right): \delta=7.28(\mathrm{t}, J=7.2 \mathrm{~Hz}, 2 \mathrm{H})$, $7.22(\mathrm{~d}, J=6.0 \mathrm{~Hz}, 2 \mathrm{H}), 7.16\left(\mathrm{tt}, J_{\mathrm{a}}=1.6 \mathrm{~Hz}, J_{\mathrm{b}}=8.4 \mathrm{~Hz}, 1 \mathrm{H}\right), 6.58$ (s, 1H), $6.52(\mathrm{~s}, 1 \mathrm{H}), 4.70(\mathrm{~d}, J=6.4 \mathrm{~Hz}, 1 \mathrm{H}), 4.20-4.11(\mathrm{~m}, 1 \mathrm{H})$, $3.83(\mathrm{~s}, 3 \mathrm{H}), 3.80(\mathrm{~s}, 3 \mathrm{H}), 3.78-3.71(\mathrm{~m}, 1 \mathrm{H}), 2.98-2.86(\mathrm{~m}, 1 \mathrm{H})$, 2.83-2.71 (m, 2H), 2.65-2.56 (m, 1H), 2.23-2.01 ppm (m, 2H);

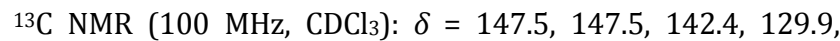
128.5, 128.3, 126.1, 125.7, 111.5, 107.8, 74.8, 63.2, 56.0, 55.8, 37.8, 31.4, 28.6 ppm; HRMS $m / z$ (ESI) calcd. for $\mathrm{C}_{19} \mathrm{H}_{22} \mathrm{NaO}_{3}[\mathrm{M}$ $+\mathrm{Na}]^{+}:$321.1467, found 321.1465 .

1-(4-Trifluoromethyl-phenyl)-1,3,4,9-tetrahydro-pyrano[3,4b]indole (7m). Pale yellow liquid; ${ }^{1} \mathrm{H}$ NMR (400 MHz, $\mathrm{CDCl}_{3}, 25$ $\left.{ }^{\circ} \mathrm{C}\right): \delta=7.61(\mathrm{~d}, J=8.1 \mathrm{~Hz}, 2 \mathrm{H}), 7.55(\mathrm{~d}, J=6.8 \mathrm{~Hz}, 2 \mathrm{H}), 7.47(\mathrm{~d}, J$ $=8.0 \mathrm{~Hz}, 2 \mathrm{H}), 7.24-7.19(\mathrm{~m}, 1 \mathrm{H}), 7.18-7.09(\mathrm{~m}, 2 \mathrm{H}), 5.82(\mathrm{~s}$, $1 \mathrm{H}), 4.36-4.22(\mathrm{~m}, 1 \mathrm{H}), 4.03-3.88(\mathrm{~m}, 1 \mathrm{H}), 3.15-3.01(\mathrm{~m}, 1 \mathrm{H})$, 2.89-2.77 ppm (m, $1 \mathrm{H})$; ${ }^{13} \mathrm{C}$ NMR (100 MHz, $\left.\mathrm{CDCl}_{3}\right): \delta=143.6$, 136.3, 132.7, 131.3, 131.0, 130.0, 128.8, 128.4, 128.0, 127.0, 
$126.1,125.9,125.8,125.5,125.4,122.7,122.4,120.0,118.6$, 111.2, 109.2, 75.5, 64.9, 22.3 ppm; HRMS $m / z$ (ESI) calcd. for $\mathrm{C}_{18} \mathrm{H}_{14} \mathrm{~F}_{3} \mathrm{NNaO}[\mathrm{M}+\mathrm{Na}]+:$ 340.0925, found 340.0922 .

\section{Results and discussion}

Initially, four $\mathrm{SiO}_{2}$-supported policresulen catalysts were prepared through a simple procedure, which involved (1) mixing an aqueous solution of policresulen (52 wt\%) and silica together in ethanol solvent; and (2) removing the volatile solvent under reduced pressure after $30 \mathrm{~min}$ of stirring. The $\mathrm{SO}_{3} \mathrm{H}$ loadings of the catalysts were $0.20,0.50,1.00$ and $1.50 \mathrm{mmol} / \mathrm{g}$. The catalysts produced were all fine powders (see the photo in Fig. 1). It should be noted that, with this method, the obtained catalysts also contained a small amount of water. Fortunately, this was easily quantified using the following procedure: (1) unmodified silica was subjected to TG analysis to determine the initial amount of absorbed water; (2) the increase in the weight of the silica material after the immobilization of policresulen was measured, and the weight contributed by pure policresulen was removed. The water contents of all the catalysts were found to be nearly the same, ranging from $15 \mathrm{wt} \%$ to $17 \mathrm{wt} \%$ of the hybrid composite. Two reference catalysts, $\mathrm{SiO}_{2}$-supported sulfonic acid and $\mathrm{TiO}_{2}$-supported benzenesulfonic acid were used for comparison in this study. The former was prepared according to our previous method $[39,40]$, whereas the latter was prepared based on a modified literature method (see Electronic Supplementary Information (ESI)) [41,42]. The schematic structures of all the prepared catalysts are shown in Fig. 1. Some physico-chemical properties of the materials are given in the ESI. Compared with those of the reference material, unmodified $\mathrm{SiO}_{2}$, a new set of absorption peaks appeared in the IR spectra of policresulen/SiO2. The bands and their assignments are as follows: The hydroxyl group stretching vibration $v(0-\mathrm{H})$ at $3451 \mathrm{~cm}^{-1}$ increased in intensity, indicating the presence of hydroxyl groups in the structure of policresulen. The absorption peaks at $1579,1541,1491,1456$, and $1408 \mathrm{~cm}^{-1}$ can be ascribed to stretching vibrations of the aromatic ring $v(\mathrm{C}-\mathrm{C}) / v(\mathrm{C}=\mathrm{C})$. Peaks appearing at $691,577,550 \mathrm{~cm}^{-1}$ also in-

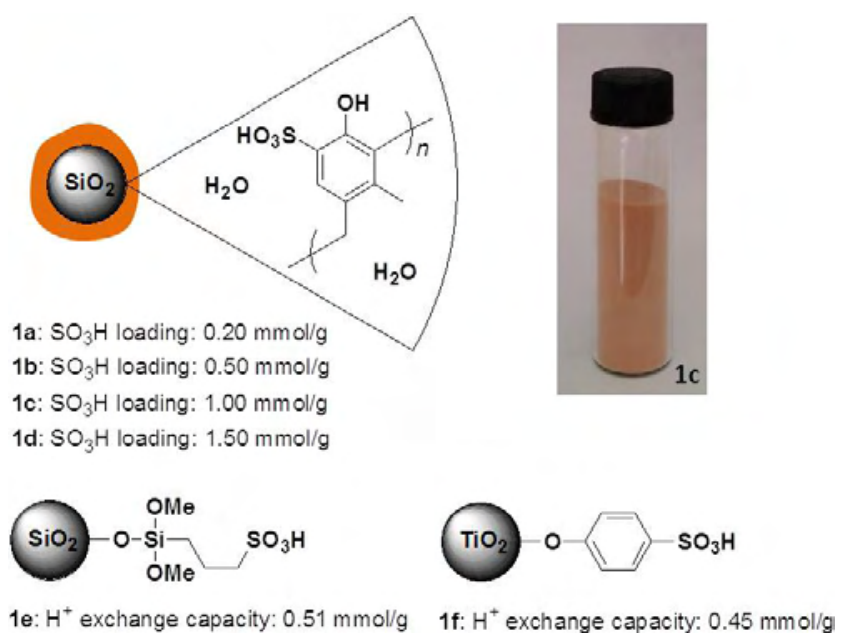

Fig. 1. Schematic representation of solid-supported catalysts used in this study and photo of prepared catalyst 1c. dicated the existence of aromatic structure in the policresulen $/ \mathrm{SiO}_{2}$ catalyst. Meanwhile, the BET surface areas decreased with increase of policresulen loading.

After determining that we had successfully synthesized the desired catalytic materials, we applied them to selected organic reactions. $\beta$-Alkylations of styrene with alcohols are important $\mathrm{C}-\mathrm{C}$ bond forming reactions, and many metal complexes or acids have been investigated as catalysts [43-45]. Because the only by-product of this type of reaction is water, it has been considered as a green route for the synthesis of multi-substituted olefins $[46,47]$. However, most of the reported catalysts are homogeneous species and cannot be recycled. Although a few heterogeneous catalysts have also been employed [48], they suffer from either a time-consuming preparation procedure or call for task-specific experimental tools that are generally inaccessible in a typical organic synthesis lab. To address these drawbacks, our silica/policresulen catalysts, which can be prepared within $1 \mathrm{~h}$ without using special instruments, were employed in the nucleophilic substitution of benzhydrol 2a with styrene 3a. As shown in Table 1, no product was obtained in the absence of catalyst (entry 1). The present silica/policresulen composite catalyst was indeed effective for promoting this reaction. With catalyst $\mathbf{1 a}$, which contained a low policresulen loading, the desired product $\mathbf{4 a}$ was obtained in only moderate yield after $5 \mathrm{~h}$ of reaction at $80{ }^{\circ} \mathrm{C}$ in 1,2-dibromoethane (entry 2). The yield of $\mathbf{4 a}$ increased with policresulen loading, and when $\mathbf{1 b}$ was used, it reached $92 \%$ under identical conditions (entry 3). However, no significant improvement in yield was observed when $\mathbf{1 b}$ was replaced with $1 \mathbf{c}$ (entry 4). It should be noted that blank $\mathrm{SiO}_{2}$ and $\mathrm{TiO}_{2}$ were proven to be inactive for this reaction (entry 5). Therefore, the catalytic activity of $\mathbf{1 b}$ can be attributed to its coating of policresulen. The reaction also proceeded smoothly with the

\section{Table 1}

Nucleophilic substitution of benzhydrol with styrene over different catalysts.

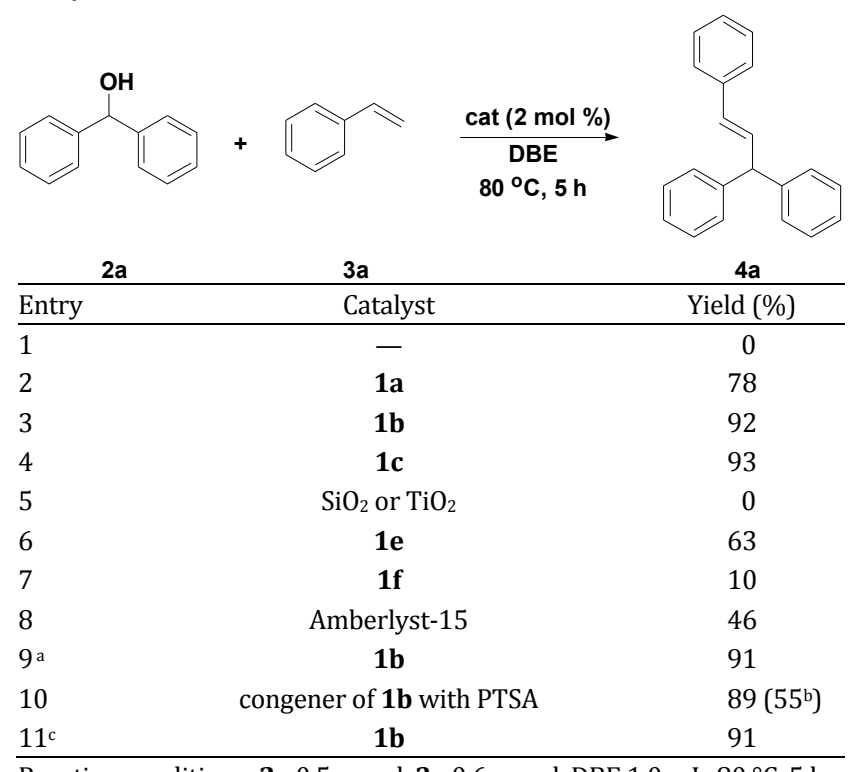

Reaction conditions: 2a $0.5 \mathrm{mmol}$, 3a $0.6 \mathrm{mmol}$, DBE $1.0 \mathrm{~mL}, 80^{\circ} \mathrm{C}, 5 \mathrm{~h}$ a $\mathbf{1 b}$ was reused in the fourth run. ${ }^{\mathrm{b}}$ the catalyst was reused in the first run. ${ }^{c} 5.0 \mathrm{mmol}$ scale reaction. 
$\mathrm{SiO}_{2}$-supported sulfonic acid catalyst 1e. However, the obtained yield was far inferior to that obtained with $\mathbf{1 b}$ (entry 6). To our surprise, although the acidic species of the $\mathrm{TiO}_{2}$-supported benzenesulfonic acid catalyst $1 \mathbf{f}$ has a similar molecular structure, a very low yield was obtained with this catalyst (entry 7). Although we are uncertain as to the reasons behind this discrepancy in performance, the poor catalytic activity of $\mathbf{1 f}$ can be partially ascribed to insufficient contact between the catalyst and substrate, which is a result of the poor flexibility of the chemically bonded benzenesulfonic acid. A commonly used resin-supported acid, Amberlyst-15, was also examined, and only moderate yield was obtained under identical conditions (entry 8). These results indicate that silica/policresulen composites are indeed able to act as acid catalysts to promote organic reactions. Because the policresulen component is insoluble in DBE, the silica/policresulen composite catalyst $\mathbf{1 b}$ could be recovered easily by filtration at the end of the reaction. After 20 min of treatment at $80{ }^{\circ} \mathrm{C}$ under vacuum conditions $(10$ $\mathrm{mmHg}$ ), the recovered catalyst was subjected to the next run. With this procedure, 1b could be reused at least four times without significant loss in its activity (entry 9). A congener of 1b produced using toluenesulfonic acid (PTSA) as the acidic component ( $\mathrm{SiO}_{2}$-PTSA) was also used as a catalyst for the model reaction. Although good catalytic activity was obtained in the first run, its recyclability was far from satisfactory (entry 10). This result demonstrated that the policresulen component was key to rendering this immobilization protocol possible. Notably, the reaction could also be effectively scaled up by 10 times with similar efficiency (entry 11).

With the optimized conditions in hand, we probed the scope of the reaction with respect to both the styrene and the benzhydrol components. As evidenced by the results shown in Table 2, both electron-rich and moderately electro-poor styrenes reacted smoothly with benzhydrol, producing the substitution products in generally good to excellent yields. Styrene with methyl or phenyl at the $\alpha$-position of the double bond was afforded with the aid of catalyst $\mathbf{1 b}$ in moderate or excellent yield. The scope of the reaction with respect to the benzhydrol component was then investigated and was found to be good also. Several benzhydrol derivatives with methyl, methoxy, fluoro or chloro groups readily participated in the reaction with styrene, affording the corresponding tri-substituted ethylene in good to excellent yields.

Tertiary benzyl alcohols can undergo a dehydration reaction under acidic conditions to form styrene-type products [49]. Based on this mechanism, Han et al. [50] recently developed a tandem dehydration/nucleophilic substitution reaction involving two different alcohols. We found that this type of transformation can also be performed in our system with the aid of $\mathbf{1 b}$. As shown in Scheme 1, two benzhydrol-type alcohols reacted smoothly under the above-mentioned optimum conditions, providing the expected multi-substituted olefin $\mathbf{4 h}$ in $96 \%$ yield, which is quite competitive compared with the result obtained for the condensation reaction of 1,1-diphenylethylene with benzhydrol over the same catalyst.

Encouraged by the promising results obtained in the above-mentioned reactions, we then applied the sili-
Table 2

Substrate scope of $\mathbf{1 b}$-catalyzed nucleophilic substitution of benzhydrols with styrenes.

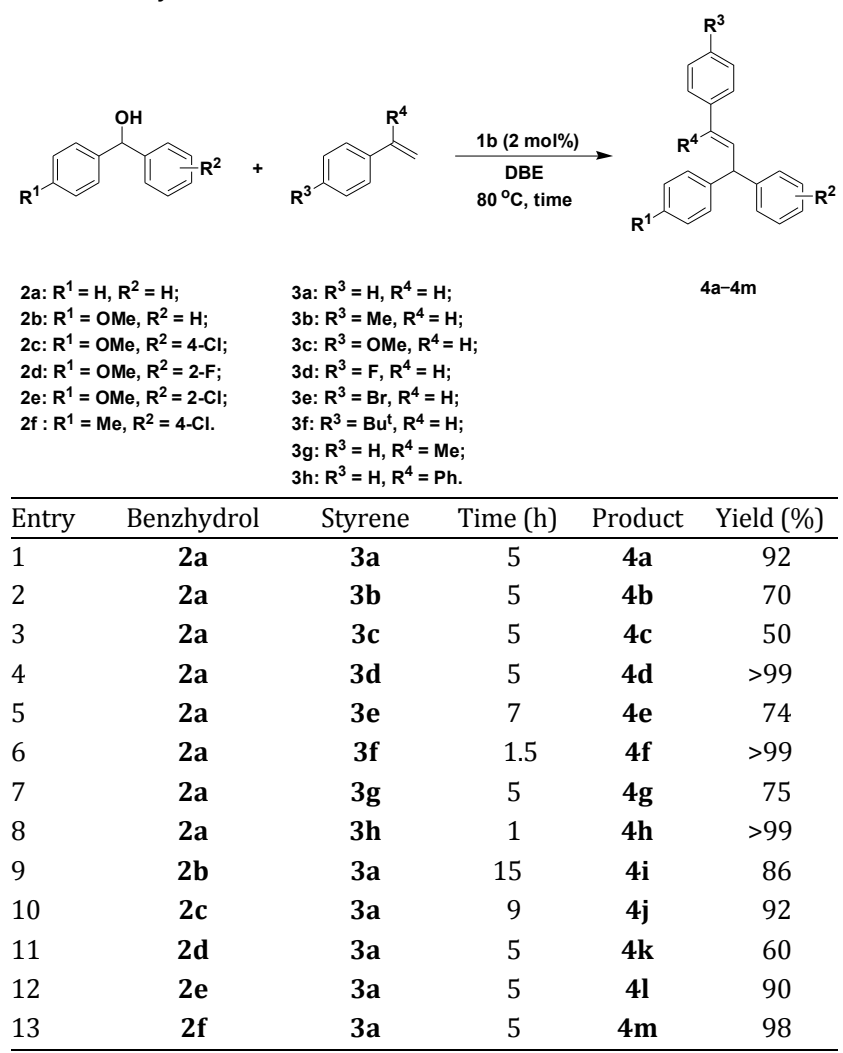

Reaction conditions: 2a $0.5 \mathrm{mmol}$, 3a $0.6 \mathrm{mmol}, \mathbf{1 b} 2 \mathrm{~mol} \%$, DBE $1 \mathrm{~mL}$, $80^{\circ} \mathrm{C}$.

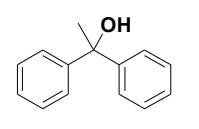

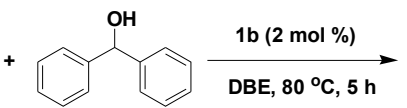

2a

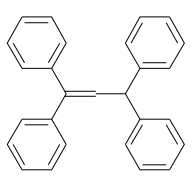

$4 h, 96 \%$
Scheme 1. Tandem dehydration/nucleophilic substitution reaction of two different alcohols over catalyst $\mathbf{1 b}$.

ca/policresulen composite catalyst to the oxa-Pictet-Spengler reaction of 2-phenylethanol and benzaldehyde. This type of condensation relies heavily on the use of acid catalysts [51-55], and has been extensively used for the synthesis of isochromans. Although heterogeneous catalysts are preferable from the viewpoint of green chemistry, they are still rarely used in oxa-Pictet-Spengler reactions. Until now, there has been only one report on the use of a solid catalyst, a small pore size zeolite Ersorb-4 [56]. This is a clinoptilolite-type zeolite material with high Si content (Si:Al ratio 5:1). Unfortunately, this kind of zeolite is inaccessible to most labs working in organic chemistry. We found that, in the presence of a catalytic amount of $\mathbf{1 b}$, 2-(3,4-dimethoxyphenyl)ethanol $\mathbf{5 a}$ reacted readily in 1,2-dichloroethane with benzaldehyde $6 \mathbf{a}$ at $80{ }^{\circ} \mathrm{C}$, affording the expected isochroman 7a in 96\% yield after $5 \mathrm{~h}$ (Table 3, entry 1 ). In this reaction, catalyst $\mathbf{1 b}$ could also be recycled at least three times without significant loss in activity. Increasing 
Table 3

Oxa-Pictet-Spengler reaction catalyzed by solid acid catalysts.

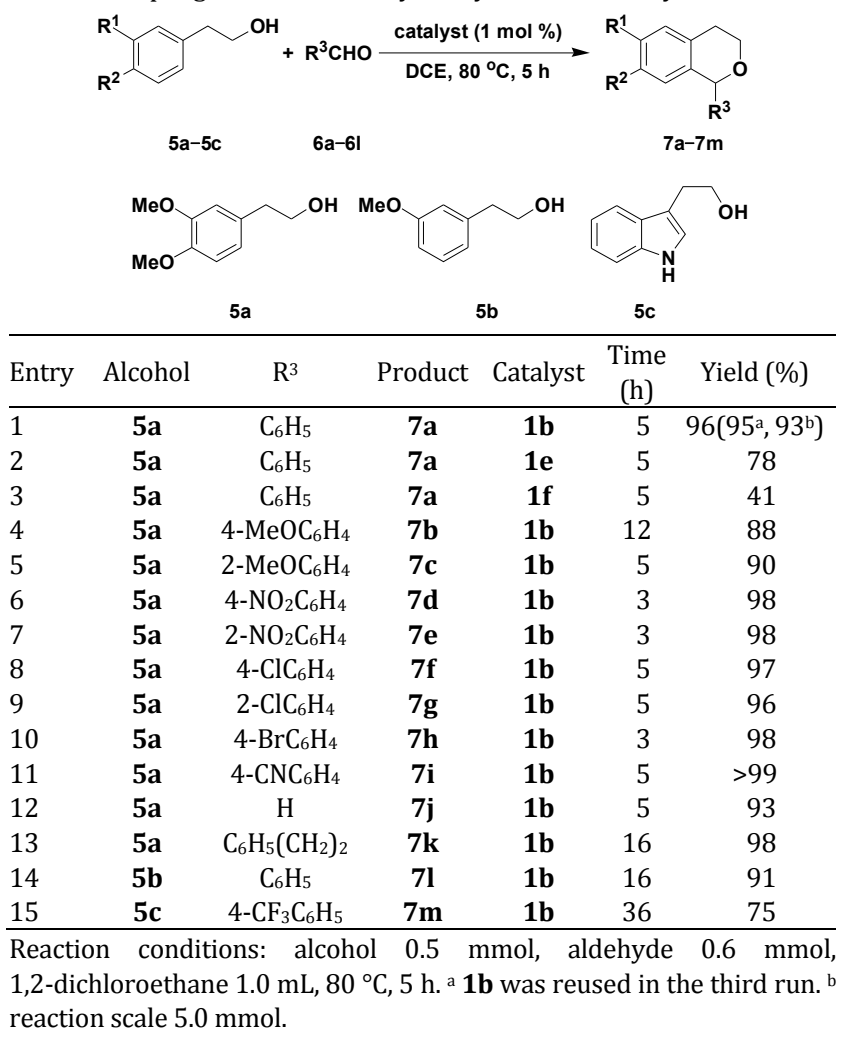

the reaction scale from 0.5 to $5.0 \mathrm{mmol}$ did not significantly influence the synthetic efficiency. However, when $\mathrm{SiO}_{2}$-supported sulfonic acid $\mathbf{1 e}$ was used as catalyst, the yield of $7 \mathbf{a}$ reached only $78 \%$ (entry 2). The reaction with $\mathrm{TiO}_{2}$-supported benzenesulfonic acid catalyst 1 ff proceeded sluggishly, affording $\mathbf{7 a}$ in only $41 \%$ under identical conditions (entry 3).

Subsequently, other aldehydes and alcohols were subjected to the conditions used for entry 1 (Table 3). First, we selected a set of aldehydes spanning a convenient spectrum of lipophicity and reactivity and used $\mathbf{5 a}$ as the only source of the required alcohol. When $\mathbf{1 b}$ was used as the catalyst, the results for all the aldehydes, which included both aromatic and aliphatic aldehydes, largely paralleled those obtained with benzaldehyde (entries 4-13). The reaction appeared to be insusceptible to the presence of a substituent in the $\mathrm{C} 2$ position of benzaldehyde; 2-methoxybenzaldehyde, 2-nitrobenzaldehyde, and 2-chlorobenzaldehyde reacted as well as their C4-substituted congeners (entries 4-9). Under the present conditions, a cyano group could be delivered into the final product without any structural damage (entry 11). 3-Methoxyphenethyl alcohol $\mathbf{5 b}$ and tryptophol $\mathbf{5 c}$ could also be used as counter substrates of the aldehyde component. Thus, catalyst $\mathbf{1 b}$ was proved again to be effective for these oxa-Pictet-Spengler reactions (entries 14 and 15).

The silica/policresulen composite catalystwas also used in the 3-alkenylation of indoles with 1,3-dicarbonyl compounds, which can produce valuable $\mathrm{C} 3$-substituted indoles. The use of some Lewis or Brønsted acids, such as $\mathrm{FeCl}_{3}$ [57], $\mathrm{I}_{2}$ [58], acidic ionic liquid [59], and an Au (III) salt catalyst [60] has been examined for this reaction. However, all these catalysts are homogeneous and cannot be recycled. Using $\mathbf{1 c}$ as the catalyst, 2-methylindole 8a reacted smoothly with methyl acetoacetate 9a in toluene, affording the corresponding C3-alkenylated indole 10a in 90\% yield (Scheme 2). At the end of the reaction, catalyst $1 \mathbf{c}$ was easily recovered and reused at least two times without significant loss in activity. It should be noted that the same reaction over silica-supported sulfonic acid catalyst $\mathbf{1 e}$ failed to give a satisfactory result. Because only $55 \%$ yield was obtained with catalyst $\mathbf{1 b}$ under identical conditions, we deduced that the reaction might be significantly influenced by the catalyst loading. Fortunately, it is very easy to increase the loading of the policresulen component on the present catalyst. In contrast, an increase in acid loading with the conventional silica-supported sulfonic acid catalyst is not easy because it generally needs a sophisticated procedure and strict control of the preparation parameters. 2-Methylindole can also readily undergo an alkenylation with 2-phenylacetaldehyde over 1d (Scheme 2). A similar reaction using $\mathrm{FeCl}_{3}$ as the catalyst has been reported by Yang et al. [61]. An excellent yield, 94\%, was obtained after $11 \mathrm{~h}$ of stirring at room temperature. In this reaction, the recovered $\mathbf{1 d}$ also showed good recyclability. We have thus established the first heterogeneous catalytic system for 3-alkenylation of indoles with 1,3-dicarbonyl compounds and 2-phenylaldehyde.

\section{Conclusions}

Conventional methods for heterogenizing homogeneous molecular catalysts must covalently anchor the desired catalyst molecule on a solid support, and are thus rather complex and sometimes need sophisticated operations. The present sili$\mathrm{ca} /$ policresulen system achieves the ultimate goal for moving from a homogeneous catalyst towards heterogeneous conditions: easy separation of the catalyst and products while maintaining the same activity. The distinction in our case is that the catalytically active component, policresulen, could be easily immobilized on silica without forming chemical bonds. The unique structure of policresulen is the key factor that renders this protocol possible. The hydroxyl groups of policresulen
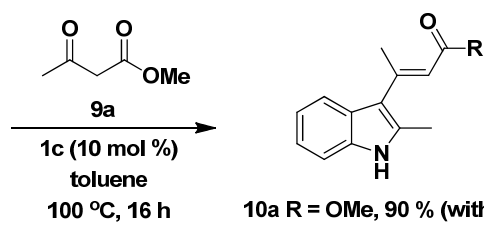

10a R = OMe, $90 \%$ (with 1f, $43 \%$; with 1b, $55 \%$ ) in the third run, $88 \%$

$10 \mathrm{~b}, 94 \%$ (in the third run $92 \%$ )
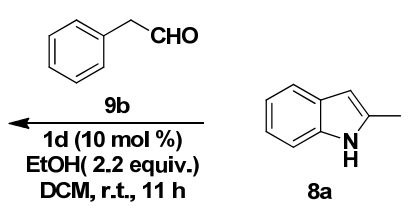

Scheme 2. C3-Alkenylation of 2-methylindoleover silica/policresulen composite catalyst. 
likely enable the formation of hydrogen bonds that facilitate its immobilization, while the sulfonic acid ensures a good catalytic activity of the composite. This catalyst exhibited good performance in various organic reactions, including $\beta$-alkylation of styrenes with benzhydrol, oxa-Pictet-Spengler reactions, and C3-alkenylation of indoles with 1,3-dicarbonyl compounds. However, we wish to point out that the catalytic reaction might occur in a homogeneous aqueous phase formed at the surface of the silica, and that the use of an organic solvent that cannot dissolve the policresulen component allows the catalyst to remain stable on the solid component. Because this unique composite catalyst can be easily prepared without the use of any special instruments, researchers working in both catalytic reaction and organic synthesis may find it of use in the future.We are actively working on exploration of other reactions with this catalyst with the hope of clarifying its application scope and limitations.

\section{References}

[1] Clark J H, Macquarrie D J. Handbook of Green Chemistry and Technology. Oxford: Wiley-Blackwell, 2002. 86

[2] Tatsumi T, Sheldon R A, Van Bekkum H. Fine Chemicals Through Heterogeneous Catalysis. New York: Wiley-VCH, 2001. 185

[3] Akiyama T. Chem Rev, 2007, 107: 5744

[4] Corma A, Garcia H. Chem Rev, 2003, 103: 4307

[5] Busca G. Chem Rev, 2007, 107: 5366

[6] Kozhevnikov I V.J Mol Catal A, 2007, 262: 86

[7] Kobayashi S, Manabe K. Pure Appl Chem, 2000, 72:1373

[8] Pan X J, Li M H, Gu Y L. Chem Asian J, 2014, 9: 268

[9] Corma A. Curr Opin Solid State Mater Sci, 1997, 2: 63

[10] Tanabe K, Holderich W F. Appl Catal A, 1999, 181: 399

[11] Corma A, Garcia H. Catal Today, 1997, 38: 257

[12] Song X, Sayari A. Catal Rev-Sci Eng, 1996, 38: 329

[13] Corma A. Chem Rev, 1995, 95: 559

[14] Kozhevnikov I V. Chem Rev, 1998, 98: 171

[15] Lotero E, Liu Y, Lopez D E, Suwannakarn K, Bruce D A, Goodwin J G Jr. Ind Eng Chem Res, 2005, 44: 5353

[16] Vilcocq L, Castilho P C, Carvalheiro F, Duarte L C. ChemSusChem, 2014, 7: 1010
[17] Melero J A, Iglesias J, Morales G. Green Chem, 2009, 11: 1285

[18] Rinaldi R, Schueth F. ChemSusChem, 2009, 2: 1096

[19] Cejka J, Wichterlova B. Catal Rev-Sci Eng, 2002, 44: 375

[20] Zabeti M, Daud W M A W, Aroua M K. Fuel Proc Technol, 2009, 90: 770

[21] Wilson K, Clark J H. Pure Appl Chem, 2000, 72: 1313

[22] Pastor I M, Yus M. Curr Org Chem, 2007, 11: 925

[23] Vaidya T, Eisenberg R, Frontier A J. ChemCatChem, 2011, 3: 1531

[24] Nakajima K, Hara M. ACS Catal, 2012, 2: 1296

[25] Harmer M A, Sun Q. Appl Catal A, 2001, 221: 45

[26] Salehi P, Ali Zolfigol M, Shirini F, Baghbanzadeh M. Curr Org Chem, 2006, 10: 2171

[27] Okuhara T. Chem Rev, 2002, 102: 3641

[28] Brunel D, Blanc A C, Galarneau A, Fajula F. Catal Today, 2002, 73: 139

[29] Van Doorslaer C, Wahlen J, Mertens P, Binnemans K, De Vos D. Dalton Trans, 2010, 39: 8377

[30] Steinrueck H P, Wasserscheid P. Catal Lett, 2015, 145: 380

[31] Werner S, Szesni N, Kaiser M, Haumann M, Wasserscheid P. Chem Eng Technol, 2012, 35: 1962

[32] Gu Y L, Li G X. Adv Synth Catal, 2009, 351: 817

[33] Zhao F, Fujita S J, Arai M. Curr Org Chem, 2006, 10: 1681

[34] Riisager A, Fehrmann R, Haumann M, Wasserscheid P. Eur J Inorg Chem, 2006: 695

[35] Riisager A, Fehrmann R. Ionic Liquids in Synthesis. 2nd Ed. New York: Wiley-VCH, 2008. 527

[36] Tundo P, Perosa A, Zecchini F. In: Perosa A, Zinovyev S ed. Methods and Reagents for Green Chemistry. New York: John Wiley \& Sons, 2007.131

[37] Kilmarx P H, Limpakarnjanarat K, Supawitkul S, Korattana S, Young N L, Parekh B S, Respess R A, Mastro T D, St Louis M E. AIDS, 1998, 12: 767

[38] Marrero-Ponce Y, Meneses-Marcel A, Castillo-Garit J A, Machado-Tugores Y, Escario J A, Barrio A G, Pereira D M, Nogal-Ruiz J J, Aran V J, Martinez-Fernandez A R, Torrens F, Rotondo R, Ibarra-Velarde F, Alvarado Y J. Bioorg Med Chem, 2006, 14: 6502

[39] Gu Y L, Azzouzi A, Pouilloux Y, Jerome F, Barrault J. Green Chem, 2008, 10: 164

[40] Sun S H, Bai R X, Gu Y L. Chem Eur J, 2014, 20: 549

[41] Kamegawa T, Matsuura S, Seto H, Yamashita H. Angew Chem Int $E d, 2013,52: 916$

\section{Graphical Abstract}

Chin. J. Catal., 2015, 36: 1606-1613 doi: 10.1016/S1872-2067(15)60910-X

\section{Silica-supported policresulenas a solidacid catalyst for organic} reactions

Kexing Zeng, Zhipeng Huang, Jie Yang, Yanlong Gu*

Huazhong University of Science and Technology;

Lanzhou Institute of Chemical Physics, Chinese Academy of Science

A new type of solid catalyst was prepared by coating a thin layer of policresulen, a commercially available drug, onto the surface of silica. The obtained silica/policresulen composite showed remarkable catalytic activity for various organic reactions.

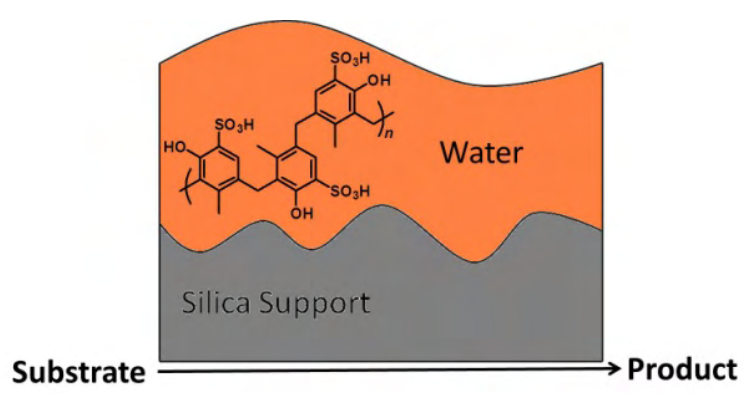

Salient features: low cost; easy to prepare; high efficiency; good recyclability and diverse applications in catalysis. 
[42] Notestein J M, Iglesia E, Katz A. Chem Mater, 2007, 19: 4998

[43] Yue H L, Wei W, Li M M, Yang Y R, Ji J X. Adv Synth Catal, 2011, 353: 3135

[44] Liu Z Q, Zhang Y, Zhao L, Li Z, Wang J, Li H, Wu L M. Org Lett, 2011, 13: 2208

[45] Huang G B, Wang X, Pan Y M, Wang H S, Yao G Y, Zhang Y. J Org Chem, 2013, 78: 2742

[46] Kumar R, Van der Eycken E V. Chem Soc Rev, 2013, 42: 1121

[47] Emer E, Sinisi R, Capdevila M G, Petruzziello D, De Vincentiis F, Cozzi P G. Eur J Org Chem, 2011, 4: 647

[48] Aoyama T, Koda S, Takeyoshi Y, Ito T, Takidoa T, Kodomari M. Chem Commun, 2013, 49: 6605

[49] Gu Y L, Karam A, Jerome F, Barrault J. Org Lett, 2007, 9: 3145

[50] Han F, Yang L, Li Z, Zhao Y, Xia C. Adv Synth Catal, 2014, 356: 2506

[51] Saito A, Takayama M, Yamazaki A, Numaguchi J, Hanzawa Y. Tet- rahedron, 2007, 63: 4039

[52] Saeed A. Chin Chem Lett, 2010, 21: 261

[53] Bouguerne B, Hoffmann P, Lherbet C. Synth Commun, 2010, 40: 915

[54] Lherbet C, Soupaya D, Baudoin-Dehoux C, André C, Blonski C, Hoffmann P. Tetrahedron Lett, 2008, 49: 5449

[55] Li M H, Taheri A, Liu M, Sun S H, Gu Y L. Adv Synth Catal, 2014, 356: 537

[56] Hegedus A, Hell Z. Org Biomol Chem, 2006, 4: 1220

[57] Yadav J S, Subba Reddy B V, Praneeth K. Tetrahedron Lett, 2008, 49: 199

[58] Singh N, Singh K N. Synlett, 2012, 23: 2116

[59] Santra S, Majee A, Hajra A. Tetrahedron Lett, 2011, 52: 3825

[60] Arcadi A, Alfonsi M, Bianchi G, D'Anniballe G, Marinelli F. Adv Synth Catal, 2006, 348: 331

[61] Yang Q, Wang L D, Guo T L, Yu Z K. J Org Chem, 2012, 77: 8355

\title{
$\mathrm{SiO}_{2}$ 担载聚甲酚磺醛作为固体酸催化剂用于有机反应
}

\author{
曾科星 ${ }^{\mathrm{a}, \dagger}$ ，黄志鹏 $\mathrm{a}, \dagger$ ，杨 杰 ${ }^{\mathrm{a}}$ ，顾彦龙 $\mathrm{a}, \mathrm{b}, *$ \\ a华中科技大学化学与化工学院, 教育部大型电池关键材料与系统重点实验室, 湖北武汉 430074 \\ $\mathrm{b}^{\mathrm{b}}$ 中国科学院兰州化学物理研究所, 羰基合成与选择氧化国家重点实验室, 甘肃兰州 730000
}

摘要: 均相催化多相化是催化化学研究热点之一. 但是, 很多固体催化剂的制备需要专门的仪器设备和长期的实验技术积累, 而 一般的有机合成化学实验室并不具备制备和调控固体催化剂的条件. 另外, 部分固体催化剂制备过程较为复杂, 制备周期较长, 因此, 人们在进行有机转化反应操作时往往倾向于采用均相催化剂. 为了改变这一现状, 需要尽快发展制备方法简单、周期短、 性能可靠的固体催化剂, 以期能够在当前化学反应绿色化过程中做出更大贡献.

酸催化剂广泛用于有机合成反应. 传统硫酸、氢氟酸等均相酸催化剂虽然催化活性较好, 但其腐蚀性强、毒性大, 且回收困 难. 为了提高化学转化过程的绿色性, 固体酸催化剂在有机反应中的应用已广受关注. 但是, 传统的固体酸催化剂制备过程大多 较为复杂, 获取周期长, 且酸度不均、负载量也难以实现调控, 因此有必要发展一种制备便捷、酸度适中、普适性广的固体酸催化 剂. 聚甲酚磺醛是2-羟基-4-甲基苯磺酸与甲醛的低聚物, 不溶于二氯甲烷、乙酸乙酯等大部分有机溶剂, 易溶于水. 聚甲酚磺醛的 水溶液已经被用作治疗妇科疾病的药物, 是一种廉价、易得、生物兼容性好的市售化学品. 由于聚甲酚磺醛分子结构中含有大量 的磺酸基, 因此其具备作为酸催化剂的潜质. 考虑到其骨架结构中富含大量羟基, 可能与 $\mathrm{SiO}_{2}$ 类多羟基载体产生氢键作用, 因而 可在一定程度上稳定制备的 $\mathrm{SiO}_{2} /$ 聚甲酚磺醛复合固体材料. 本文采用浸渍法, 经如下两步将聚甲酚磺醛负载于 $\mathrm{SiO}_{2}$ 表面, 制备了 一系列担载量不同 $(0.2 \sim 1.5 \mathrm{mmol} / \mathrm{g})$ 的复合酸性材料: (1) 将 $\mathrm{SiO}_{2}$ 加入聚甲酚磺醛水溶液的乙醇溶液中, 在室温下磁力摚拌10-15分 钟; (2)在减压条件下除去水和乙醇(约30分钟). 整个制备过程, 无需专门的设备, 仅需使用磁力摚拌器和旋转蒸发仪等一般有机 合成实验室的常规仪器, 并且制备周期非常短, 在 1 小时以内即可完成. 该方法所制备催化剂的负载量可由投料比直接控制, 可简 单、快速制备负载量不同的 $\mathrm{SiO}_{2} /$ 聚甲酚磺醛复合固体材料.

研究发现, $\mathrm{SiO}_{2} /$ 聚甲酚磺醛复合固体催化剂能够高效地促进多种有机反应, 如二苯甲醇与苯乙烯衍生物的亲核取代反应、2苯基乙醇与醛的oxa-Pictect-Spengler反应以及吲哚与1,3-二羰基化合物或2-苯基乙醛的直接 $\mathrm{C} 3$-烯基化反应. 在上述反应中, 目标 产物的产率均较高, 且反应对底物具有良好的官能团兼容性. $\mathrm{SiO}_{2} /$ 聚甲酚磺醛催化剂均可重复使用多次, 且催化活性无明显下 降. 更重要的是, 上述反应的投料量可增加至 $10 \mathrm{mmol}$, 且产物的分离产率无明显下降, 从而证明 $\mathrm{SiO}_{2} /$ 聚甲酚磺醛催化剂具有一定 的实际合成价值. 值得一提的是, 由于 $\mathrm{SiO}_{2}$ 聚甲酚磺醛催化剂含有一定量的水, 本文认为聚甲酚磺醛在 $\mathrm{SiO}_{2}$ 表面是以水溶液的形 式存在, 因此在反应过程中可能是以均相催化的方式进行.

相较于传统的 $\mathrm{SiO}_{2}$ 负载磺酸、 $\mathrm{TiO}_{2}$ 负载苯磺酸以及Amberlyst-15催化剂, $\mathrm{SiO}_{2} /$ 聚甲酚磺醛复合固体酸催化剂具有活性高、制 备周期短、廉价易得的特点. 同时, 该催化剂可简单、快速制备各种不同酸负载量的固体催化剂, 在一定范围内调控该类固体酸 催化剂的酸性. 因而, $\mathrm{SiO}_{2} /$ 聚甲酚磺醛复合固体酸催化剂望用于各种酸催化合成反应中.

关键词: 固体酸催化剂; 聚甲酚磺醛; 酸催化; 催化剂固载化; 烷基化

收稿日期: 2015-04-25. 接受日期: 2015-05-22. 出版日期: 2015-09-20.

*通讯联系人. 电话: (027)87543032; 传真: (027)87544532; 电子信箱: klgyl@hust.edu.cn

†共同第一作者.

基金来源：国家自然科学基金(21173089，21373093); 中央高校基本科研业务费专项资金(2014ZZGH019); 湖北省催化协同创新 中心资助.

本文的英文电子版由Elsevier出版社在ScienceDirect上出版(http://www.sciencedirect.com/science/journal/18722067). 